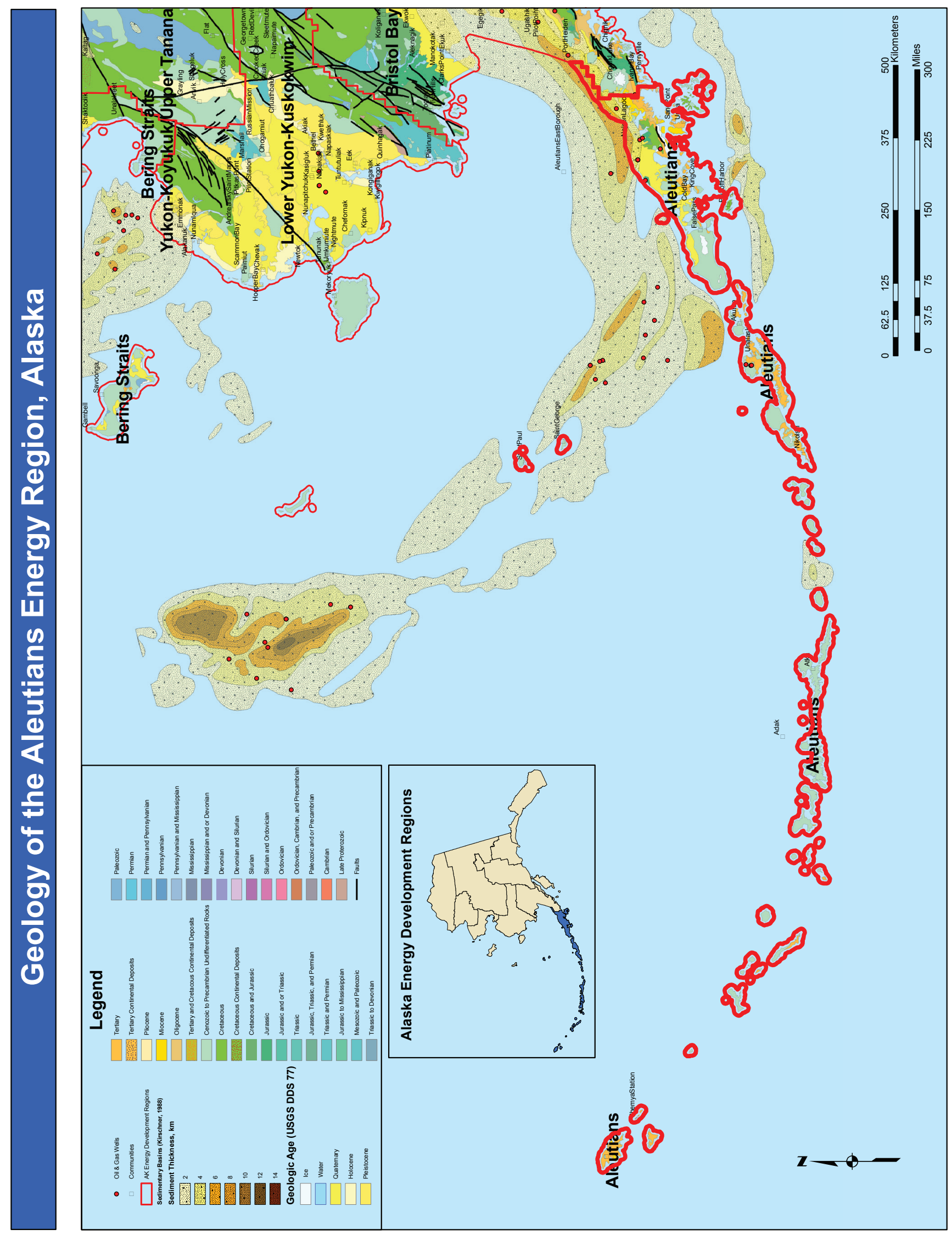





\section{SUMMARY OF FOSSIL FUEL AND GEOTHERMAL RESOURCE POTENTIAL IN THE ALEUTIANS ENERGY REGION}

by Paul L. Decker, Robert J. Gillis, Ken Helmold, and Shaun Peterson

\section{INTRODUCTION}

\section{Purpose of this report}

Economic growth and stability in Alaska's rural and urban areas hinges partially, if not primarily, on the availability of affordable and sustainable energy supplies. Recent price increases in oil and gas commodities have created severe economic hardship in many areas of the state that are dependent on diesel and heating oil as their primary source of energy. All sectors of Alaska's economy rely on affordable energy sources with limited pricing volatility, highlighting the need to diversify the energy portfolio by developing locally available and sustainable resources that are not tied to the global market. Unfortunately, all areas are not created equal in energy accessibility; the resources available for local exploitation vary widely across the state. It is critical that funding decisions for expensive programs to reduce the dependence on diesel for heat and electricity take into account information concerning the entire suite of natural resources that exist in a given area.

This report draws from existing information to provide community and state leaders an objective summary of our current knowledge concerning the potential of locally exploitable fossil fuel and geothermal energy resources in the Aleutians energy region (fig. B1), one of 11 regions recognized by the Alaska Energy Authority in their Energy Plan (AEA, 2009). The potential geologically hosted energy resources considered here include exploitable coal, conventional and unconventional oil and gas, and geothermal resources. This report concludes with recommendations as to what additional data or strategies, if any, would provide the most leveraging in helping to develop new energy resources in the region.

Readers without geological training are encouraged to peruse the geologic summaries of fossil fuel resources and geothermal energy in Chapter A. They provide an overview of the geologic elements that must be present in an area to economically develop coal, conventional oil and gas, unconventional oil and gas, and geothermal resources. These summaries will provide the necessary background to more fully understand the information presented in this chapter.

\section{Geographic and geologic setting}

The Aleutians Energy Development Region extends more than 1,350 miles, including all of the Aleutian Island chain and the southwesternmost Alaska Peninsula to approximately Mt. Veniaminof (fig. 1 and sheet 2). A thin strip along the western coast extends farther northeastward to southwest of Port Heiden. Also included are the remote Pribilof Islands to the north, located more than 200 miles from other land areas, near the middle of the Bering Sea. Energy resources in this region, with the exception of geothermal, are limited to the vicinity of the southwestern tip of the Alaska Peninsula and 3 miles northwest of the coast into the adjacent Bristol Bay. Villages in the Aleutian Development Region range in population from more than 4,000 to only 20 persons;

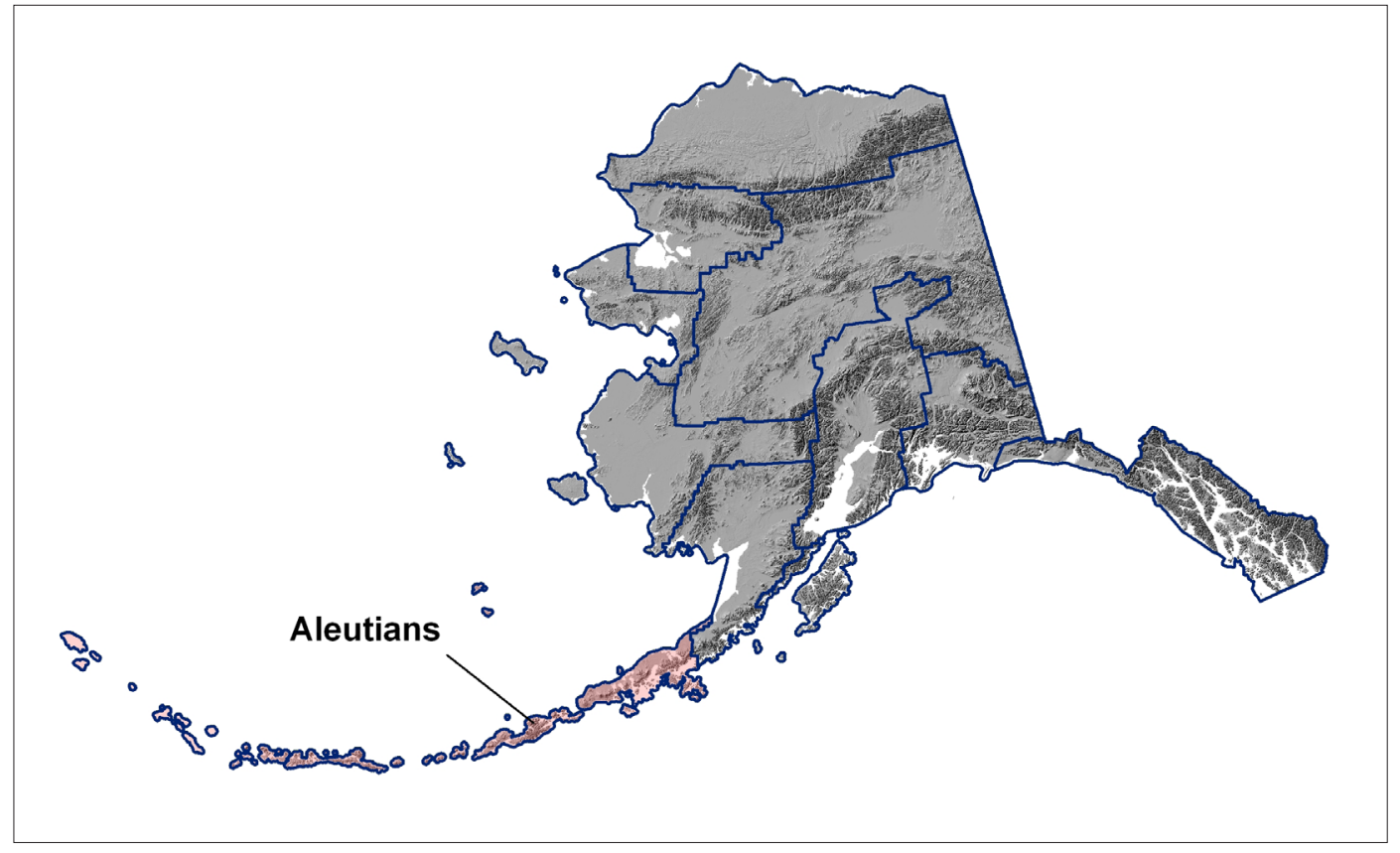

Figure B1. Location map of Aleutians Energy Region. 
all reside at tidewater and are only accessible by boat or plane. The largest village is Unalaska with a population of about 4,300 . Villages with populations of about 1,000 to 500 , in descending order, include Sand Point, King Cove, Akutan, and Saint Paul (in Bristol Bay). Villages with populations of about 300 to 100 include Adak and Saint George (in Bristol Bay). The villages of Atka, Cold Bay, Nelson Lagoon, False Pass, and Nikolski have populations of about 100 or less, with Attu Station near the tip of the Aleutian chain being the smallest at 20 persons.

The geography of the region consists of a diverse mix of volcanic islands, lowland topography, rugged hills, and conical glaciated mountains that rise abruptly from the landscape. Islands of the Aleutian chain are volcanic in origin and extend westward from the southwestern tip of the Alaska Peninsula over 1,000 miles into the North Pacific Ocean. The islands can be elongate, conical, or irregularly shaped and vary in size from 1 mile to tens of miles wide and many more in length. Each island can have any combination of low relief, rugged hills, or peaks up to 9,000 feet or more. The southwestern end of the Alaska Peninsula includes glaciallysculpted lowlands on the northwestern side that support numerous freshwater lakes. The Aleutian Range on the southeastern side of the peninsula is characterized by rolling hills and rugged low mountains composed of commonly tilted Cenozoic age volcanic rocks and folded and faulted Mesozoic age through Cenozoic age sedimentary strata. The boundary between the geographically distinct sides of the peninsula is punctuated by a few tall, conical, volcanic edifices such as Mount Veniaminof and Pavlof Volcano.

Most of the Aleutians Development Region is the product of millions of years of accumulation of volcanic flows and detritus above a subduction zone where the oceanic Pacific plate is currently being thrust toward the northwest beneath the North American plate. Magma generated at this plate boundary has intruded oceanic crust of the overriding North American plate, resulting in an arcuate array of volcanoes referred to as a volcanic island arc. Where these intrusions occur in North American plate continental crust along the Alaskan Peninsula, they form a continental volcanic arc. Major episodes of arc volcanism have occurred at least three times on the Alaska Peninsula over the past 200 million years (Reed and Lanphere, 1969; Wilson, 1985; Amato and others, 2007). The most recent volcanism along the Aleutian chain was initiated about 35 million years ago (Wilson, 1981), and continues to be the dominant geologic process shaping the Aleutians Development Region today. Rocks exposed on the Aleutian Islands consist mostly of igneous and associated sedimentary rocks younger than about $40-45$ million years. These rocks formed after major plate tectonic changes in the North Pacific that led to the creation of the present-day Aleutian subduction zone (Worrall, 1991). In contrast, on the Alaska Peninsula and along a belt stretching northwest beneath the Bering Sea toward the Pribilof Islands, bedrock includes much older Mesozoic sedimentary units as well as the younger Cenozoic sedimentary rocks deposited in a collection of basins positioned north of the volcanic arc. The largest and deepest of these are the North Aleutian and Saint George basins in the Bristol Bay area. The Umnak, Amak Plateau, and Sanak basins are shallower or more restricted offshore sedimentary basins in the area east of Unalaska.

Very little is known about the pre-Mesozoic geologic evolution of the Alaska Peninsula area. However, very thick sequences of Mesozoic strata record the development of a major sedimentary basin. These sediments were largely derived from erosion of a nearby igneous arc and include organic-rich rocks that are important components of the petroleum system in the adjacent Bristol Bay and Cook Inlet basins (Detterman and Hartsock, 1966; Decker and others, 2008). Subsequent cycles of tectonic subsidence and uplift since Late Cretaceous time are responsible for the coalbearing rocks in the northwestern area of the development region (Detterman and others, 1996), as well as many of the petroleum reservoir rocks in the adjacent petroleum basins (Calderwood and Fackler, 1972; Detterman and others, 1996; Helmold and others, 2008). Faulting and folding associated with these tectonic processes during Cenozoic time are responsible for generating most of the hydrocarbon traps for these petroleum systems and conduits for hot fluids in geothermal systems. However, this same deformation adds a component of risk to the area's energy potential by introducing faults and fractures that may breach hydrocarbon traps or partition formerly continuous coal fields.

\section{GEOLOGIC ENERGY RESOURCE POTENTIAL IN THE ALEUTIANS ENERGY REGION \\ Mineable coal resource potential}

Aleutians Development Region. Coal resources and occurrences exist only on the southern Alaska Peninsula portion of the development region, and are not found on the Aleutian Islands. Coal-bearing rocks near tidewater extend from Pavlof Bay northeastward approximately 200 miles to the Dog Salmon River (Conwell and Triplehorn, 1978) in the Bristol Bay Development Region. However, much of the intervening area is covered by younger volcanic rocks and Quaternary glacial deposits that obscure the coal-bearing strata. The two main southern peninsula regions with coal exposures are the Herendeen Bay Field, near Herendeen Bay, and Unga Island Field, on Unga Island (fig. B2). Villages within 100 miles of these coal locations include Port Heiden, Nelson Lagoon, Sand Point, King Cove, Cold Bay, and False Pass.

Herendeen Bay Field. The Herendeen Bay field is near the southwestern tip of the Alaska Peninsula (fig. B2). Coal in the field is derived primarily from the Coal Valley Member of the Upper Cretaceous Chignik Formation, with minor occurrences in the middle to upper Miocene Bear 


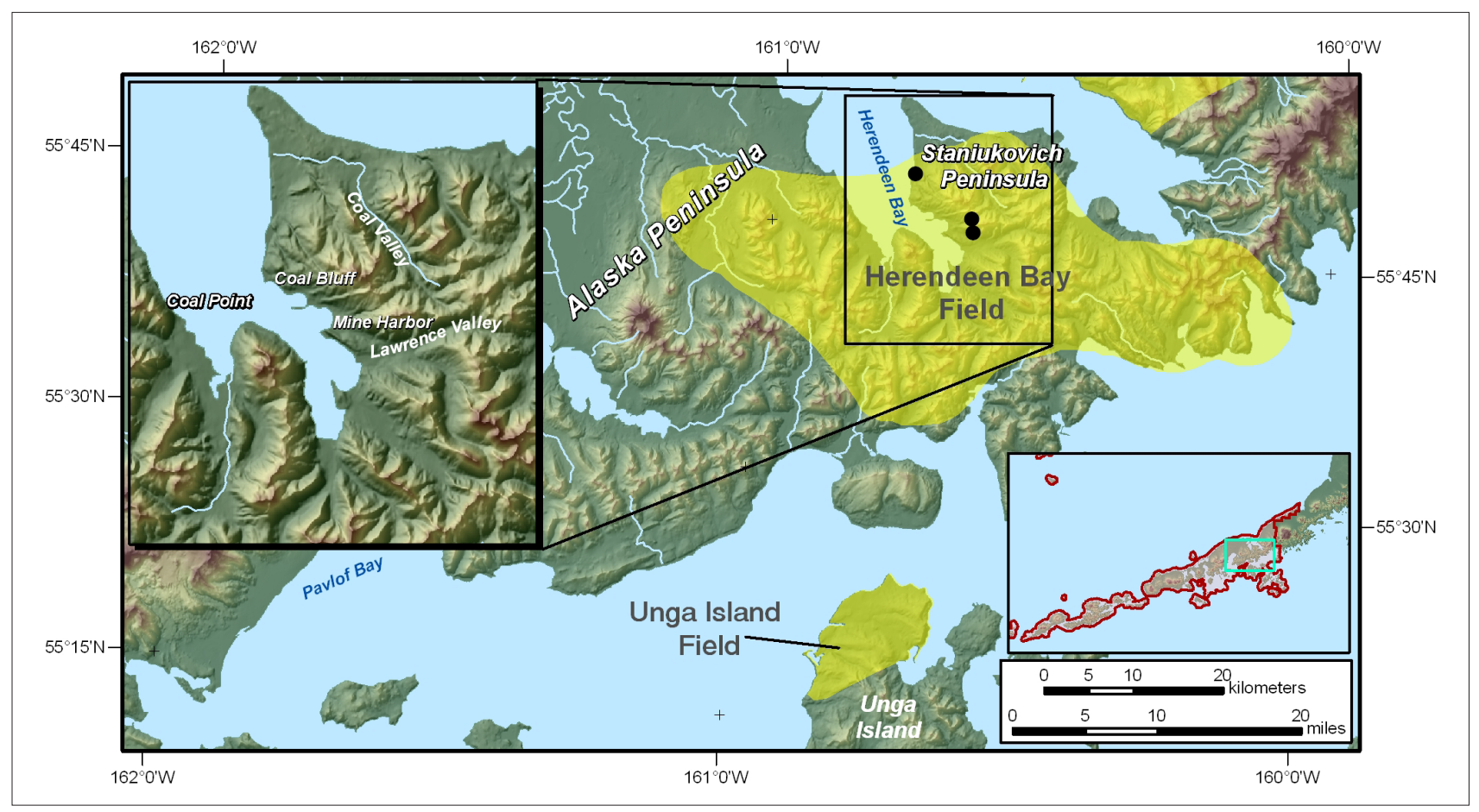

Figure B2. Location map of the eastern Aleutians Energy Region showing selected geographic references noted in the text (note inset detailed map of Staniukovich Peninsula). Black dots indicate reported coal occurrences; yellow-shaded areas inferred to be underlain by coal-bearing rocks.

Lake Formation in the vicinity of Bear Lake. Coal-bearing strata of the Chignik Formation occupy at least 130 square kilometers, with principal exposures at Mine Creek (Mine Harbor area), Coal Bluff, Coal Valley and east of Coal Valley, Lawrence Valley, and Coal Point (Merritt, 1986a; Merritt and McGee, 1986). In the area of Coal Point, coals are discontinuously exposed along the beach for 6.5 kilometers (Merritt and McGee, 1986. The coal has a high-volatile bituminous B rank and high ash content (Merritt, 1986a; Merritt and McGee, 1986). Heating values of about 12,000 $\mathrm{Btu} / \mathrm{lb}$ can be achieved after washing the coal (Conwell and Triplehorn, 1978). Fifteen coalbeds have been identified in the lower Chignik Formation at these locations with typical thicknesses of 2 feet or less (Atwood, 1911). However, bed thicknesses vary considerably over short lateral distances (Merritt and McGee, 1986) and one report indicated a coal unit up to 10 feet thick (Paige, 1906). Merritt and McGee (1986) estimate total coal resources in the Herendeen Bay field to be about 138 million short tons (125 million metric tons). Chignik Formation strata in the area, primarily on the Staniukovich Peninsula due east of Herendeen Bay, are commonly displaced by faults with several meters to 300 meters of offset (Merritt and McGee, 1986). This is especially true for the area due east of Coal Bluff, where faulting is particularly common (Decker and others, 2008). Such structural complexities disrupt the continuity of coalbeds and can hamper their extraction. Coal studies in this area have consisted of field work in the 1980s that included measured stratigraphic sections and coal quality analyses (Merritt and McGee, 1986). Additional work involving geologic field mapping accompanied by stratigraphic and coal quality studies and exploratory drilling are required to better define the reserves in this area. Merritt (1987) mentions that exploratory drilling for coal has been performed in the Herendeen Bay field and/or Unga Island field in the past, but provides no further details, and no additional information has been uncovered for this report. Although not a particularly large coal reserve as currently understood, the relatively high heating value of its coal and proximity to tidewater may make the Herendeen Bay field, along with the Chignik field in the Bristol Bay development region to the northeast, an attractive target for future study. However, the Herendeen Bay field is part of the Pavlof Unit of the Alaska Peninsula National Wildlife Preserve and surface access for further geologic investigations and potential exploitation of the resource would need to be researched carefully.

Unga Island field. The Unga Island coal field is located on Unga Island, the largest of the Shumagin Islands, about 3.5 miles off the northwestern coast of the Alaska Peninsula near Pavlof Bay and approximately 265 miles southwest of Kodiak Island (fig. B2). Coals in the Unga Island field are derived from the lower to middle Miocene Unga Conglomerate unit. Most are of low rank, yielding relatively low heating values. The coals are typically lignite, but include less abundant 
beds of subbituminous $\mathrm{C}$ coal. Limited analyses reveal that the coal is commonly low in ash and sulfur, with heating values between 8,486 and 12,120 Btu/lb. Bed thicknesses are no greater than 3 feet, and are often less (Merritt, 1986b). Furthermore, the thicker beds often have non-coal partings that detract from their economic value. Merritt (1986b) estimates 90 million short tons of inferred coal in beds more than 1 foot thick, and 70 million short tons in beds more than 1.6 feet thick - values that are consistent with a previous estimate of 150 million short tons of hypothetical reserves (Alaska Division of Energy and Power Development, 1977). In 1977, the Alaska Division of Energy and Power Development listed the Unga Island coal field as not a significant economic energy resource, but rather possibly best suited for local use only. Merritt (1986b) later reported that the Unga Island field coals had a low economic development potential based on his findings of mostly thin coalbeds in the area, their low ranking, and extraction technology at the time.

\section{Conventional oil and gas resource potential}

As explained in the discussion of requirements for exploitable oil and gas resources (Chapter A), functioning petroleum systems occur in thick sedimentary basins, and require three basic elements: Effective source rocks, reservoirs, and traps. Each of the elements must be in existence and connected at the time hydrocarbons are generated and migrated. This section provides an overview of the various basins in the Aleutians region and then considers each of the necessary elements of petroleum systems in turn to evaluate the role conventional oil and gas resources may play in supplying rural energy to the region.

Overview of sedimentary basins. Sheet 1 shows the distribution of sedimentary basins (after Kirschner, 1988) that could potentially host petroleum systems in the Aleutians region. The North Aleutian, Amak, Umnak Plateau, St. George, and Sanak basins developed mostly in offshore areas of the northeastern part of the region during Tertiary time. There is very little evidence for thick sedimentary basins on or near the Aleutian volcanic arc west of Unalaska. Hence, the following discussion of petroleum systems elements applies only to the easternmost Aleutian Islands, southwestern Alaska Peninsula, and the Pribilof Islands. The greatest potential for exploration and development of conventional hydrocarbon resources in the region is in the North Aleutian basin on and just offshore from the southwestern Alaska Peninsula (sheet 1).

Source rocks. Outcrop studies have documented oilprone source rocks in the Upper Triassic Kamishak Formation and the Middle Jurassic Kialagvik Formation, but these units are likely to be present only in certain areas of the Aleutians energy region (McLean, 1977, 1979; Comer and others, 1987; Wang and others, 1988; Sherwood and others, 2006; Decker, 2008). They have generated both oil and gas found in natural seeps near their limited outcrop area, located in federally protected lands near Puale Bay and Wide Bay on the southeastern side of the Alaska Peninsula in the Bristol Bay and Kodiak energy regions (Magoon and Anders, 1992). These oil source rocks, or their age equivalents, are probably present in the subsurface of the easternmost part of the Aleutians energy region on the southwestern Alaska Peninsula. The Cathedral River Unit \#1 well drilled northeast of Cold Bay encountered possible oil-prone shales in the Kialagvik Formation, but the presence of oil-based drilling additives in the well raises questions about the reliability of the source rock data from the well (Sherwood and others, 2006). No other wells on the southwestern Alaska Peninsula drilled deep enough to penetrate the Kialagvik and Kamishak Formations or their equivalents, but vitrinite reflectance and burial histories indicate these potential sources long ago reached a thermal maturity level too high for oil production, and are now candidates for gas generation (Molenaar, 1996). Upper Jurassic units were penetrated at the bottom of several wells in the St. George basin, suggesting the likely presence of the Middle Jurassic to Late Triassic source rocks or their equivalents at somewhat greater depth. However, no evidence for Mesozoic-sourced oil or gas has been found in overlying Tertiary strata and effective generation of hydrocarbons from these sources in the St. George basin remains unproven (Sherwood and others, 2006).

Gas-prone sources are more widespread in the sedimentary basins of the Aleutian region, consisting of both shallow marine shales and non-marine coaly strata of Tertiary age (McLean, 1987 Sherwood and others, 2006; Decker, 2008). Both biogenic and thermogenic gas may be present in some parts of the region's sedimentary basins. However, as stated in the discussion of requirements for exploitable resources of conventional oil and gas (see Chapter A), viable accumulations of biogenic gas are unlikely except where recent uplift may have occurred along the southern edge of the North Aleutian basin on the northwest side of the Alaska Peninsula.

The most promising area for thermogenic gas charge appears to be near the southern margin of the North Aleutian basin offshore from Nelson Lagoon and Port Moller. Here, the basin reaches depths consistent with thermogenic hydrocarbon generation (Sherwood and others, 2006; Decker and others, 2005; Decker, 2008). This observation helps explain patterns of nearby oil and gas leasing and the industry's advocacy to allow exploration drilling in adjacent federal waters (Anchorage Daily News, 2005; Shell Exploration and Production, 2008). The deeper parts of the St. George, Amak, and Umnak Plateau basins also have some potential for thermogenic generation from gas-prone Tertiary source rocks (Comer and others, 1987; Sherwood and others, 2006). However, none of the 12 wells that tested the St. George basin encountered any hydrocarbon accumulations (Sherwood and others, 2006). This represents a non-specific failure of the petroleum system that could stem from a 
variety of causes: Insufficient source rock quantity or quality; problems relating to migration paths; leaky traps or seals; or the timing of trap formation. The Amak, Sanak, and Umnak Plateau basins remain undrilled and are poorly understood. Many of the attributes of these remote basins challenge the viability of possible gas exploration.

Reservoir rocks. Several Tertiary formations likely have adequate thickness of sandstone with sufficient porosity and permeability to serve as reservoirs for either oil or gas. In the North Aleutian basin in particular, much of the Miocene Bear Lake Formation has been widely observed to maintain reservoir quality in outcrop and in wells that encountered it at depth (McLean, 1987; Turner and others, 1988; Sherwood and others, 2006; Decker and others, 2005, 2006). Younger strata also maintain high porosity and permeability, but are too shallow to host effective traps or maintain sufficient reservoir pressure. Alteration of the sandstone after burial has locally degraded the reservoir quality in most formations (Lyle and others, 1979; Turner and others, 1988; Helmold and others, 2008) and should be considered as one component of the overall exploration risk.

Mesozoic formations of the southwestern Alaska Peninsula contain thick sandstones and some limestones that could serve as hydrocarbon reservoirs. Reservoir quality data for these units is limited to select outcrop samples from the Alaska Peninsula that dominantly record porosity values of less than 10 percent and permeabilities typically below $0.10 \mathrm{md}$ (Reifenstuhl and others, 2005; Strauch and others, 2006). Although these data indicate suboptimal reservoir quality in the Mesozoic, the sample set is small, limited to surface samples, and excludes potentially more promising parts of the Jurassic section (Reifenstuhl and others, 2005). In special cases, early entrapment of hydrocarbons can prevent porosity destruction in sandstone reservoirs, and hydrothermal alteration can create secondary porosity in limestone formations. Nevertheless, the presence of clays and other altered grains suggests that encountering reservoirquality rock in the Mesozoic strata will be a primary challenge to exploration in the region.

Traps. The southwestern Alaska Peninsula and adjacent Tertiary basins have undergone several episodes of deformation related largely to strike-slip processes during Tertiary time (Worrall, 1991; Detterman and others, 1996; Decker and others, 2005). Potential structural traps vary from simple anticlines to structurally complex folds and faults that may create traps for hydrocarbons in the subsurface (Sherwood and others, 2006; Decker and others, 2008). Stratigraphic and unconformity trap configurations are likely to have developed on the flanks of large uplifts such as the Black Hills uplift (Worrall, 1991). Low-permeability silty mudstones capable of sealing hydrocarbons accumulated in traps have recently been documented in several formations on the Alaska Peninsula (Bolger and Reifenstuhl, 2008), but their lateral extent may be limited by restricted nonmarine to marginal marine depositional environments. Although there are likely many trapping geometries developed in the structures of the area, repeated folding and faulting present an exploration risk because trap integrity can sometimes be compromised by leaky faults, fractures, or inadequate seals. An onshore trapped accumulation of hydrocarbons would be most amenable to development for local rural energy markets. However, further evaluation and definition of possible onshore traps would require the collection of significant additional seismic data over large areas where the bedrock of interest is covered by surficial deposits.

Summary of conventional oil and gas resource potential. Sedimentary basins capable of hosting conventional petroleum resources are present only in the eastern part of the Aleutian energy region. Effective source rocks, reservoir rocks, and untested traps are known or likely to be present in different areas of these sedimentary basins. Because these elements of the petroleum system have not yet been proven to coexist and interact to form exploitable accumulations of either oil or gas, the region remains only lightly explored. Based on existing information, the most likely useable conventional hydrocarbon resource is gas derived from coaly Tertiary source rocks, forming accumulations in Tertiary sandstones in structural or stratigraphic traps in offshore or nearshore areas of the southern North Aleutian basin along the northwest side of the Alaska Peninsula.

\section{Unconventional oil and gas resource potential}

Coalbed methane. In the Aleutians energy region, coal resources are only present on the southern Alaska Peninsula. The Herendeen Bay coal field, near the southwestern tip of the Alaska Peninsula, is the largest field in the region (fig. B2). The coal has a high-volatile bituminous B rank but is restricted to beds with thicknesses of 2 feet or less (Atwood, 1911). As such, they may be too thin and too discontinuous to produce sufficient coalbed methane to support development. Nevertheless, the geology of the area is complex and has not been extensively explored; reports of rapid lateral changes in coal thickness (Merritt, 1986a) allow for the possibility of thicker coal seams in the subsurface that might house a potential methane resource. Drilling logs of oil and gas exploration wells have noted high gas kicks on subsurface coal seams up to 20 feet thick on the Alaska Peninsula (Tyler and others, 2000). The Herendeen Bay coal occurrences are in the Pavlof Unit of the Alaska Peninsula National Wildlife Preserve, and any future exploration or development may be severely limited or prohibited because of that designation. Additional coals are present in the Unga Island coal field on Unga Island (fig. B2). They are mostly of low rank (lignite and less abundant beds of subbituminous C) with bed thicknesses no greater than 3 feet (Merritt, 1986b). The low thermal maturity of these coals combined with their limited thickness suggests they would be ineffective for coalbed methane development. 
Tight gas sands. As noted above, several Tertiary formations have adequate thickness of sandstone with sufficient porosity and permeability to serve as conventional reservoirs for oil and gas. These sands typically have porosities in excess of 20 percent and permeabilities greater than $10 \mathrm{md}$ (Helmold and others, 2008); the result is that reservoir quality is not sufficiently degraded for these sands to be considered tight gas sands.

Many of the Mesozoic sandstones in the Aleutian region, in particular the Staniukovich and Naknek Formations, have been relatively deeply buried and have undergone significant compaction and cementation. Porosities are typically less than 10 percent and permeabilities less than $0.1 \mathrm{md}$ are routinely recorded (Reifenstuhl and others, 2005; Strauch and others, 2006). These older, more lithified sandstones have potential as tight gas sands, particularly those subjected to brittle fracturing in addition to burial diagenesis. Extensive regional fractures have been observed in outcrops of some of the Mesozoic sandstones, particularly the Naknek Formation. These fractures are typical of tight gas sands and may well signal the presence of an unconventional, fractured reservoir. Additionally, these Mesozoic sandstones overlie several candidate hydrocarbon source rocks that could provide the necessary charge to fill a tight reservoir.

Shale gas. One of the primary requirements for shale gas is an organic-rich source rock present in the thermogenic gas window that is sufficiently brittle to host a natural fracture system. As noted above, the most promising area for thermogenic gas charge is in the southern margin of the North Aleutian basin offshore from Nelson Lagoon and Port Moller. Deeper parts of the St. George basin may have some potential for thermogenic generation from gas-prone Tertiary source rocks (Comer and others, 1987; Sherwood and others, 2006), but none of the wells in the basin encountered any hydrocarbon accumulations (Sherwood and others, 2006). Most of the Tertiary source rocks probably lack the welldeveloped fracture system necessary for efficient shale gas production.

Outcrop and well data indicate the Mesozoic source rocks are mostly oil prone (Decker, 2008). Although associated gas is possible, available information suggests shale gas potential is limited. However, recent advances in drilling technology have resulted in the production of oil directly from this type of oil-prone source rock (termed shale oil). Although this resource type has never been considered in this region, the high quality of the Triassic and Jurassic source rocks indicates this unconventional play may have potential.

Gas hydrates. The primary occurrences of gas hydrates in nature are in modern deep marine sediments, or in the shallow sediments of petroleum-rich basins in arctic regions that maintain a well-developed, continuous permafrost layer. The southerly latitude and maritime climate influence in the Aleutians energy region has resulted in very limited and discontinuous permafrost and is therefore not prospective for onshore hydrate accumulations. Alternatively, the potential for concentrations of deep marine gas hydrates is unknown, but would be limited to deeper parts of the Aleutian Trench and exceedingly expensive to test.

\section{Geothermal resource potential}

Geothermal prospectivity in the Aleutians energy region is greater than in any other Alaska Energy Authority (AEA) defined energy region in the State. Twelve occurrences of thermal spring temperatures in excess of $165^{\circ} \mathrm{F}\left(74^{\circ} \mathrm{C}\right)$ have been measured at various locations in the region. By comparison, only five such occurrences have been measured in Alaska outside the Aleutians Energy Region (Motyka and others, 1983).

Makushin Volcano, located on Unalaska, remains one of the state's best understood and most viable geothermal development prospects. Two thermal springs with discharge temperatures in excess of $165^{\circ} \mathrm{F}\left(74^{\circ} \mathrm{C}\right)$, including the state's hottest $\left(305.6^{\circ} \mathrm{F}\left[152^{\circ} \mathrm{C}\right]\right)$, are located on the flanks of Makushin Valley (Motyka and others, 1983; sheet 2) Three wells (Geothermal D-1, Geothermal E-1, and St. Makushin 1) were drilled in the area in 1982-1983, but ongoing property ownership issues have hampered development of this resource.

Akutan Island contains several chloride-rich thermal springs with surface temperatures ranging from $104^{\circ} \mathrm{F}$ to $183^{\circ} \mathrm{F}\left(40^{\circ} \mathrm{C}-84^{\circ} \mathrm{C}\right)$. These springs are in Hot Springs Bay Valley, within 3 miles of Akutan Harbor and Akutan village, and represent potentially viable direct-use applications for residential and commercial energy. Measured fumarole temperatures in the area are as high as $210^{\circ} \mathrm{F}\left(99^{\circ} \mathrm{C}\right)$ and reservoir temperature estimates, taken with geothermometers, range from $356^{\circ} \mathrm{F}$ to $374^{\circ} \mathrm{F}\left(180^{\circ} \mathrm{C}-190^{\circ} \mathrm{C}\right)$ (Motyka and others, 1983). In 2010, two small diamonter temperature gradient core holes were drilled in the floor of Hot Springs Bay Valley to test the geothermal aquifers and the size and extent of the outflow zones (Kolker and others, 2012). Geothermal flow temperatures reached $359^{\circ} \mathrm{F}\left(182^{\circ} \mathrm{C}\right)$ and gas geochemistry data from fumaroles suggests reservoirs could potentially reach $572^{\circ} \mathrm{F}\left(300^{\circ} \mathrm{C}\right)$ (Kolker and others, 2012).

Geyser Bight Valley on Umnak Island hosts the most widespread and hottest chloride-rich thermal spring system in Alaska. The area includes several small geysers, numerous fumaroles, and three thermal springs with temperatures exceeding $165^{\circ} \mathrm{F}\left(74^{\circ} \mathrm{C}\right)$. Isotope geothermometry indicates deep reservoir temperatures may be as high as $491^{\circ} \mathrm{F}\left(255^{\circ} \mathrm{C}\right)$ (Motyka and others, 1983). The village of Nikolski, 25 miles southwest of Geyser Bight, could be a potential benefactor of geothermal development in this region.

Atka Island is host to three thermal springs in excess of $165^{\circ} \mathrm{F}\left(74^{\circ} \mathrm{C}\right)$, located in fumarolic fields near the flanks of Mount Kliuchef and Mount Korovin. Reservoir temperature estimates, based on gas geothermometry, are $338^{\circ} \mathrm{F}-572^{\circ} \mathrm{F}$ 
$\left(170^{\circ} \mathrm{C}-300^{\circ} \mathrm{C}\right)($ Motyka and others, 1983$)$. The proximity of these springs to the village of Atka warrants consideration as a direct-use application of geothermal energy.

Adak Island has numerous saline thermal springs near the base of Mount Adagdak. Reservoir temperature estimates of these spring waters are $320^{\circ} \mathrm{F}-374^{\circ} \mathrm{F}\left(160^{\circ} \mathrm{C}-190^{\circ} \mathrm{C}\right)$, with measured temperature gradients as high as $4.39^{\circ} \mathrm{F} / 100$ feet $\left(8^{\circ} \mathrm{C} / 100\right.$ meters) (Motyka and others, 1983) (Motyka and others, 1983). Proximity to the village of Adak could allow direct-use application if this resource is developed.

Considered as a whole, the Aleutian volcanic arc contains a number of widespread geothermal prospects including 26 thermal springs, of which 12 have surface discharge temperatures greater than $165^{\circ} \mathrm{F}\left(74^{\circ} \mathrm{C}\right)$, nine fumarole fields, and various geysers and mud pots (Motyka and others, 1983).

\section{RECOMMENDATIONS}

\section{Geothermal resource recommendations}

There is clearly a geothermal resource present in the region and numerous possibilities exist for direct use on industrial applications of this energy source in small villages across the Aleutians. The development of a directuse pilot project would provide insight into the viability of this resource in remote regions. The Makushin geothermal prospect has significant potential, although resolution of land issues and an updated risk assessment and economic analysis would be necessary precursors to development.

\section{Conventional oil and gas resource recommendations}

Previous reconnaissance-scale geologic fieldwork has established the framework geology of the Alaska Peninsula (Detterman and others, 1996). However, significant improvements in our understanding of the region's' petroleum potential could be achieved with additional detailed field mapping and stratigraphic studies. This type of work would build on the successful recent topical studies of the Alaska Peninsula by DNR geologists (Reifenstuhl and Decker, 2008).

The petroleum industry has expressed clear interest in exploring federal waters of the southern North Aleutian basin, which is considered prospective for commercial-scale natural gas discoveries (Anchorage Daily News, 2005; Shell Exploration and Production, 2008) that could also potentially make gas available to local markets within the Aleutians energy region. This cannot occur until offshore federal leasing is reinitiated.

Industry has shown only moderate interest in exploring leasable state acreage onshore and beneath state waters, which have been available since 2005 through the Alaska Peninsula areawide lease sale program. Although some limited onshore seismic data exists, there is very limited exposed bedrock geology, and acquisition of high-quality modern seismic data would be required to determine if exploration targets exist under currently accessible lands. An alternative investment strategy would be to encourage industry-led gas exploration of the federal offshore that would provide infrastructure for potential future onshore activity as well.

\section{Coal resource recommendations}

Studies of the Herendeen Bay coal in the Aleutians Energy Region are highlighted in the report by Merritt and McGee (1986), which includes measured sections and resource assessment in the Herendeen Bay area. To better define the coal resource in this area, additional detailed work involving geologic field mapping, additional stratigraphic and coal quality studies, and exploratory drilling are required. Estimates of as much as 138 million short tons of coal, along with the relatively high heating value of the coal, make it an attractive target for future study. It is recommended the State consider detailed geologic mapping in the area to determine any future energy potential. The fact that this field is located in the Pavlof Unit of the Alaska Peninsula National Wildlife Preserve should be considered in any future recommendations.

Earlier studies concluded the Unga Island coal field is not a significant economic energy resource (Alaska Division of Energy and Power Development, 1977; Merritt, 1986b) and that it has a low economic development potential due to mostly thin coalbeds in the area and their low rank. No further work evaluating the Unga coal field is recommended at this time.

\section{Unconventional oil and gas resource recommendations}

Coalbed methane. Further geologic field investigations and/or exploratory drilling could improve the understanding of coalbed methane resource potential in the Herendeen Bay area. However, based on available data, the limited stratigraphic and areal extent of coals in the region suggests commercial quantities of methane are unlikely. Investment into further investigations in this area would need to be weighed against the economics of other energy alternatives.

Tight gas sands. The possibility exists for encountering fractured tight gas sands in portions of the Mesozoic section in the region, although the probability of recovering commercial quantities of gas is low. In terms of unconventional resources, tight gas sands have the most likelihood of providing producible quantities of hydrocarbons for local use. Nevertheless, it would be difficult to entice companies to conduct commercial exploration for tight gas sands in the area. It is recommended that if the State funds tight gas sand projects, it should be done on a very local scale.

Shale gas. Based on available data, the region does not appear to host extensively fractured source rocks within the thermogenic window necessary for the generation of gas. The likelihood of finding commercial quantities of shale gas 
in the region is low and no further action is recommended at this time. However, unconventional shale oil has not been evaluated in the region and the high quality of oil-prone Mesozoic source rocks warrants further geologic study to determine its potential.

Gas hydrates. Due to the lack of extensive, continuous permafrost in most of southern Alaska, the likelihood of finding onshore gas hydrates in the region are very low, therefore no further action is recommended.

\section{REFERENCES CITED AND \\ SELECTED BIBLIOGRAPHY}

Alaska Division of Energy and Power Development, 1977, Alaska regional energy resources planning project, phase I-Alaska's energy resources findings and analysis, final report, v. I of XI, p. 93-97.

Alaska Division of Geological \& Geophysical Surveys, 1986, Summary of existing data and potential for commercial hydrocarbon accumulations, Bristol Bay, Alaska: Alaska Division of Geological \& Geophysical Surveys Public Data File 86-13, 20 p.

Alaska Energy Authority (AEA), 2009, Alaska energy-A first step toward energy independence: Alaska Energy Authority, 245 pages. Available online at http://www. akenergyauthority.org/pdf files/AK Energy Final.pdf (accessed November 12, 2009).

Amato, J.M., Rioux, M.E., Kelemen, P.B., Gehrels, G.E., Clift, P.D., Pavlis, T.L., and Draut, A.E., 2007, U-Pb geochronology of volcanic rocks from the Jurassic Talkeetna Formation and detrital zircons from pre-arc and post-arc sequences-Implications for the age of magmatism and inheritance in the Talkeetna arc, in Ridgway, K.D., Trop, J.M., Glen, J.M.G., and O’Neil, J.M., eds, Tectonic Growth of a Collisional Continental Margin-Crustal Evolution of Southern Alaska: Geological Society of America Special Paper 431, p. 253-271.

Anchorage Daily News, 2005, Bristol Bay looks good to oil firm: Anchorage Daily News, October 8, 2005, p. A1.

Atwood, W.W., 1911, Geology and mineral resources of parts of the Alaska Peninsula: U.S. Geological Survey Bulletin 467 , p. 21, p. 126-127.

Beikman, H.M., 1980, Geologic map of Alaska: U.S. Geological Survey special map, 1 sheet, scale 1:2,500,000.

Bolger, G.W., and Reifenstuhl, R.R., 2008, Mercury injection capillary pressure and reservoir seal capacity of 26 outcrop samples, Miocene to Triassic age, in Reifenstuhl, R.R., and Decker, P.L., eds., Bristol Bay-Alaska Peninsula region, overview of 2004-2007 geologic research: Alaska Division of Geological \& Geophysical Surveys Report of Investigation 2008-1D, p. 69-78.

Burk, C.A., 1965, Geology of the Alaska Peninsula-Island Arc and Continental Margin: The Geological Society of America Memoir 99, 250 p., 3 sheets.
Calderwood, K.W., and Fackler, W.C., 1972, Proposed stratigraphic nomenclature for Kenai Group, Cook Inlet basin, Alaska: American Association of Petroleum Geologists Bulletin, v. 56, p. 739-754.

Comer, C.D., Herman, B.M., and Zerwick, S.A., 1987, Geologic report for the St. George basin planning area, Bering Sea, Alaska: U.S. Minerals Management Service OCS Report MMS 87-0030, 84 p.

Conwell, C.N., and Triplehorn, D.M., 1978, Herendeen Bay-Chignik coals, southern Alaska Peninsula: Alaska Division of Geological \& Geophysical Surveys Special Report 8, 15 p., 2 sheets, scale 1:125,000.

Decker, P.L., 2008, Mesozoic and Cenozoic source-rock characteristics, Puale Bay outcrops and North Aleutian Shelf COST \#1 Well, in Reifenstuhl, R.R., and Decker, P.L., eds., Bristol Bay-Alaska Peninsula region, overview of 2004-2007 geologic research: Alaska Division of Geological \& Geophysical Surveys Report of Investigations 2008-1B, p. 11-33.

Decker, P.L., Finzel, E.S., Ridgway, K.D., Reifenstuhl, R.R., and Blodgett, R.B., 2005, Preliminary summary of the 2005 field season-Port Moller, Herendeen Bay, and Dillingham areas, Bristol Bay basin, Alaska Peninsula: Alaska Division of Geological \& Geophysical Surveys Preliminary Interpretive Report 2005-7, 55 p., 2 sheets.

Decker, P.L., Reifenstuhl, R.R., Finzel, E.S., and Helmold, K.P., 2006, Play concepts for reopening the Bristol Bay basin-Tertiary and Mesozoic petroleum systems of the Alaska Peninsula [abs.]: American Association of Petroleum Geologists Bulletin, v. 90, Program Abstracts (digital).

Decker, P.L., Reifenstuhl, R.R., Gillis, R.J., and Loveland, Andrea, 2008, Revised geologic map and structural model of the Staniukovich Peninsula-Herendeen Bay area, in Reifenstuhl, R.R., and Decker, P.L., Bristol Bay-Alaska Peninsula region, overview of 2004-2007 geologic research: Alaska Division of Geological \& Geophysical Surveys Report of Investigation 2008-1I, p. 161-176, 2 sheets, scale 1:50,000.

Detterman, R.L., and Hartsock, J.K., 1966, Geology of the Iniskin-Tuxedni region, Alaska: U.S. Geological Survey Professional Paper 512, 78 p., 6 sheets, scale 1:63,360.

Detterman, R.L., Case, J.E., Miller, J.W., Wilson, F.H., and Yount, M.E., 1996, Stratigraphic framework of the Alaska Peninsula: U.S. Geological Survey Bulletin 1969-A, 74 p.

Finzel, E.S., Reifenstuhl, R.R., Decker, P.L., and Ridgway, K.D., 2005, Sedimentology, stratigraphy, and hydrocarbon reservoir source rock potential, using surface and subsurface data, of Tertiary and Mesozoic strata, Bristol Bay basin and Alaska Peninsula: Alaska Division of Geological \& Geophysical Surveys Preliminary Interpretive Report 2005-4, 69 p.

Helmold, K.P., Brizzolara, D.W., and Reifenstuhl, R.R., 2008, Reservoir quality of 84 Tertiary sandstones from three 
exploratory wells, Bristol Bay basin, Alaska Peninsula, in Reifenstuhl, R.R., and Decker, P.L., Bristol Bay-Alaska Peninsula region, overview of 2004-2007 geologic research: Alaska Division of Geological \& Geophysical Surveys Report of Investigation 2008-1C, p. 35-67.

Kirschner, C.E., 1988, Map showing sedimentary basins of onshore and continental shelf areas, Alaska: U.S. Geological Survey Miscellaneous Investigations Series Map 1873, 1 sheet, scale 1:2,500,000.

Kolker, A., Stelling, P., Cumming, W., and Rohrs, D., 2012, Exploration of the Akutan Geothermal Resource Area: Proceedings of the 37 th Workshop on Geothermal Reservoir Engineering, Stanford University, Stanford, California, January 30-February 1, 2012, SGP-TR-194, 10 p., http://pangea.stanford.edu/ERE/pdf/IGAstandar d/SGW/2012/Kolker.pdf

Loveland, A.M., Reifenstuhl, R.R., Gillis, R.J., and Decker, P.L., 2007, Outcrop sample results from mercury injection capillary pressure analyses, Bristol Bay, Alaska Peninsula: Alaska Division of Geological \& Geophysical Surveys Raw Data File 2007-3, 11 p.

Lyle, W.M., Morehouse, J.A., Palmer, I.F., Jr., and Bolm, J.G., 1979, Tertiary formations and associated Mesozoic rocks in the Alaska Peninsula area, Alaska, and their petroleumreservoir and source-rock potential: Alaska Division of Geological \& Geophysical Surveys Geologic Report 62, 69 p., 19 sheets, scale 1:250,000.

Magoon, L.B., III, and Anders, D.E., 1992, Oil-to-source rock correlation using carbon-isotopic data and biological marker compounds, Cook Inlet-Alaska Peninsula, Alaska, in Moldowan, J.M., Albrecht, P., and Philip, R.P., eds., Biological Markers in Sediments and Petroleum: Englewood Cliffs, New Jersey, Prentice Hall, p. 241-274.

McLean, H.J., 1977, Organic geochemistry, lithology, and paleontology of Tertiary and Mesozoic rocks from wells on the Alaska Peninsula: U.S. Geological Survey OpenFile Report 77-813, 63 p.

1979, Observations on the geology and petroleum potential of the Cold Bay-False Pass area, Alaska Peninsula: U.S. Geological Survey Open-File Report 79-1605, 35 p.

1987, Federal Lands Assessment Program-Alaska Peninsula, Alaska (Province 68): U.S. Geological Survey Open-File Report 87-450-H, 7 p.

Merritt, R.D., 1986a, Alaska-Coal fields and seams 1987: Alaska Division of Geological \& Geophysical Surveys Public Data File 86-90, 55 p.

1986 b, Coal resources of the Miocene Unga Conglomerate Member, Bear Lake Formation, Unga Island, Alaska Peninsula: Alaska Division of Geological \& Geophysical Surveys Public Data File 86-69, 33 p.

1987, Evaluation of Alaska's coal potential (1982): Alaska Division of Geological \& Geophysical Surveys Public Data File 86-92, 18 p.
Merritt, R.D., and Hawley, C.C., 1986, Map of Alaska's coal resources: Alaska Division of Geological \& Geophysical Surveys Special Report 37, 1 sheet, scale 1:2,500,000.

Merritt, R.D., and McGee, D.L., 1986, Depositional environments and resource potential of Cretaceous coal-bearing strata at Chignik and Herendeen Bay, Alaska Peninsula: Alaska Division of Geological \& Geophysical Surveys Public Data File 86-72, 44 p.

Molenaar, C.M., 1996, Thermal-maturity patterns and geothermal gradients on the Alaska Peninsula, in Johnsson, M.J., and Howell, D.G., eds., Thermal evolution of sedimentary basins in Alaska: U.S. Geological Survey Bulletin 2142, p. 11-19.

Motyka, R.J., Moorman, M.A., and Liss, S.A., 1983, Geothermal resources of Alaska: Alaska Division of Geological \& Geophysical Surveys Miscellaneous Publication 8, 1 sheet, scale 1:2,500,000.

Paige, Sidney, 1906, The Herendeen Bay coal field, in U.S. Geological Survey Staff, Report on progress of investigations of mineral resources of Alaska in 1905: U.S. Geological Survey Bulletin 284, p. 101-108.

Reed, B.L., and Lanphere, M.A., 1969, Age and chemistry of Mesozoic and Tertiary plutonic rocks in south-central Alaska, Geological Society of America Bulletin, v. 80, p. 23-44.

Reifenstuhl, R.R., 2008a, Introduction, in Reifenstuhl, R.R., and Decker, P.L., eds., Bristol Bay-Alaska Peninsula region, overview of 2004-2007 geologic research: Alaska Division of Geological \& Geophysical Surveys Report of Investigation 2008-1A, p. 1-10.

2008b, Bibliography of selected references, in Reifenstuhl, R.R., and Decker, P.L., eds., Bristol Bay-Alaska Peninsula region, overview of 2004-2007 geologic research: Alaska Division of Geological \& Geophysical Surveys Report of Investigation 2008-1K, p. 207-224.

Reifenstuhl, R.R., and Decker, P.L., eds., 2008, Bristol Bay-Alaska Peninsula region, overview of 2004-2007 geologic research: Alaska Division of Geological \& Geophysical Surveys Report of Investigation 2008-1, v. 1.0.1, 223 p., 3 sheets, scale 1:50,000.

Reifenstuhl, R.R., Bailey, R.D., and Finzel, E.S., 2005, Bristol Bay and Alaska Peninsula 2004: Fieldwork and sample analyses compilation report: Alaska Division of Geological \& Geophysical Surveys Preliminary Interpretive Report 2005-1, 20 p.

Shell Exploration \& Production, 2008, North Aleutian basin, Alaska - Exploring common ground between oil and fishing: Presentation to the Alaska Resource Development Council, March 7, 2008, accessed March 10, 2008, http:// www.akrdc.org/membership/events/breakfast/0708/ nady.pdf.

Sherwood, K.W., Larson, J., Comer, C.D., Craig, J.D., and Reitmeier, C., 2006, North Aleutian basin OCS planning area assessment of undiscovered technically-recoverable 
oil and gas: U.S. Minerals Management Service-Alaska OCS Region report, 138 p., 4 plates, www.mms.gov/ alaska/re/reports/rereport.htm

Strauch, A.L., Gillis, R.J., Reifenstuhl, R.R., and Decker, P.L., 2006, 2006 Bristol Bay, Alaska Peninsula field summary and outcrop sample results from porosity and permeability and mercury injection capillary pressure analyses: Alaska Division of Geological \& Geophysical Surveys Raw Data File 2006-1, 65 p.

Turner, R.F., McCarthy, C.M., Lynch, M.B., Hoose, P.J., Martin, G.C., Larson, J.A., Flett, T.O., Sherwood, K.W., and Adams, A.J., 1988, Geological and operational summary, North Aleutian Shelf COST No. 1 well, Bering Sea, Alaska: Minerals Management Service, Alaska OCS Region, OCS Report MMS 88-089, 256 p., 2 plates.

Tyler, Roger, Scott, A.R., and Clough, J.G., 2000, Coalbed methane potential and exploration targets for rural Alaska communities: Alaska Division of Geological \& Geophysical Surveys Preliminary Interpretive Report 2000-2, 169 p.

Wang, Jason, Newton, C.R., and Dunne, Lorie, 1988, Late Triassic transition from biogenic to arc sedimentation on the Peninsular Terrane, Puale Bay, Alaska Peninsula: Geological Society of America Bulletin, v. 100, no. 9, p. 1,466-1,478.

Wilson, F.H., 1981, Map and table showing radiometric ages of rocks in the Aleutian Islands and the Alaska Peninsula: U.S. Geological Survey Open-File Report 81-471, 23 p., 1 sheet, scale 1:1,000,000.

1985, The Meshik Arc-An Eocene to earliest Miocene magmatic arc on the Alaska Peninsula: Alaska Division of Geological \& Geophysical Surveys Professional Report 88, $14 \mathrm{p}$.

Wilson, F.H., Detterman, R.L., and DuBois, Gregory, 1999, Digital data for the geologic framework of the Alaska Peninsula, Southwest Alaska, and the Alaska Peninsula Terrane: U.S. Geological Survey Open-File Report 99317, 41 p., 1 plate, scale 1:500,000, http://wrgis.wr.usgs. gov/open-file/of99-317.

Worrall, D.M., 1991, Tectonic history of the Bering Sea and the evolution of Tertiary strike-slip basins of the Bering Shelf: Geological Society of America Special Paper 257, 120 p., 1 oversize sheet, 4 plates, scale 1:2,500,000. 